Machining Performance Evaluation of Liquid Nitrogen Treated M2 Cutting Tools for Turning Operations

Department of Mechanical Engineering Symbiosis Institute of Technology (SIT) Symbiosis International (Deemed University) India.

\section{Arunkumar Bongale}

Department of Mechanical Engineering Symbiosis Institute of Technology (SIT) Symbiosis International (Deemed University)

India.

Nitin Khedkar

Department of Mechanical Engineering Symbiosis Institute of Technology (SIT) Symbiosis International (Deemed University) India.
The present study is focused on liquid nitrogen treatment of M2 tool steel for 12 hours, 24 hours, and 36 hours at $-196{ }^{\circ} \mathrm{C}$ followed by tempering at $150{ }^{\circ} \mathrm{C}$. The treated tool samples are used for machining low carbon steel on a CNC lathe to varying combinations of Spindle speed (700, $1100 \&$ $1800 \mathrm{rpm})$, Feed rate $(0.1,0.125 \& 0.15 \mathrm{rev} / \mathrm{mm})$ and Depth of cut $(0.15$, $0.3 \& 0.45 \mathrm{~mm})$. Taguchi's Design of experiments and ANOVA methods are used to statistically analyze the effect of cutting parameters and cutting forces on the tool wear and surface roughness after experimentation. SEM analysis is carried out to investigate the type of tool wear experienced by the cutting tools. The regression analysis has resulted in a model to predict the values of surface roughness, tool wear and friction coefficient, with a maximum error of $\pm 6 \%$ from the actual experimental values.

Keywords: Liquid nitrogen treatment, surface roughness, tool wear, flank wear, Taguchi, ANOVA.

\section{INTRODUCTION}

The life of cutting tools is one of the important factors which affect the production rate in the manufacturing industry. The major problem in the cutting tools during functional are tip wear and sudden failure due to the vibrations occurred, which affects the life and increases the production cost [1]. These failures can be reduced by improving the internal properties of the cutting tool materials. Currently, the materials are subjected to heat treatment followed by tempering to improve the properties of cutting tool material. Researchers have absorbed the fact that the existence of retained austenite, which is soft and unstable at low temperatures and becomes fragile during machining, is one of the main factor causing sudden failure of the cutting tool [2].

Currently, the study on Liquid nitrogen Treatment LNT to improve the properties of cutting tool materials is a general topic between researchers. LNT is an additional step after the heat treatment method and it is a one-time treatment in which the retained austenite is converted into martensite [3]. Properties such as Tensile strength [4], Hardness [5], fatigue behaviour [6] and wear resistance [7-9] were found to be increasing by the various researcher. Similarly, cryogenic treatment was used to enrich the lives of many commercial and industrial materials [10].Cryogenic treatment features a wide selection of applications such as Machining, electronic, automotive materials, food process, health and aviation [10-12]. The Temperature between -80 to $-140{ }^{\circ} \mathrm{C}$ is known as Shallow cryogenic treatment - SCT and -140 and $-196{ }^{\circ} \mathrm{C}$ is known as Liquid nitrogen treatment- LNT [13].The treatment generally includes cooling down the cutting tools below subzero temperature, using liquid nitrogen, at

Received: August 2019, Accepted: October 2019

Correspondence to: Arunkumar Bongale,

Department of Mechanical Engineering, Symbiosis

Institute of Technology (SIT), India

E-mail: arunbongale1980@gmail.com

doi: $10.5937 /$ fmet2001227S

(C) Faculty of Mechanical Engineering, Belgrade. All rights reserved a constant rate of cooling to avoid the distortion due to thermal shock damages. Cutting tools are retained at the desired temperature for a specific interval of time before bringing back to ambient temperature [14]. Ramji et al assessed surface finish by conducting the drilling operation of gray cast iron using Cryo-treated HSS drill and achieved substantial improvements in the surface finish after cryogenic treatment [15]. Reddy et al. evaluated the tool wear and surface finish of C45 steel and found that the tool wear of Cryotreated tool was minimum when compared with the untreated tool. Also noticed the decrease in the surface finish value with increased Spindle Speed for Cryotreated tool [16].

The influence of Liquid Nitrogen treatment on tool wear and life of M2 drills was studied by Firouxdor et al. [17]. The result obtained specified the rise in tool life after cryo-treatment which was due to the conversion of retained austenite to martensite and uniform distribution of carbides. Similar research was done by Cicek et al. [18], he carried out the study using M35 Cryo-treated twist drill for machining 316 stainless steel. The results indicated a $218 \%$ increase in the tool life. Thrust force and surface roughness were also found to be better in case of liquid nitrogen treated tools. Enhancement of results was mainly due to the change in retained austenite to martensite. Podgornik et al. [19] in their research work found that tool composition and type of tool plays a very vital role in the results that are obtained from by cryogenic treatment. Asiltürk et al [20] Used Taguchi approach to optimize the parameter of turning. The experiment was conducted with L9 orthogonal array and the surface roughness of AISI 4140 steel was chosen as the response parameter. The findings showed that the feed rate was the most significant parameter for surface roughness. Sahin [21] by using the Taguchi method, the tool life of CBN and ceramic inserts was compared when turning hard steels. Also, ANOVA was used to determine the impact of cutting parameters on tool life. As a result, the impact on tool life of Spindle Speed, tool hardness and feed rate was found to be $41.63 \%, 32.68 \%$ and $25.22 \%$ respectively. 
Based on the above study, the performance of Liquid nitrogen treatment of tools in comparison with heattreated and untreated was found to be improving due to its microstructural changes after the cryogenic treatment $[22,23]$. Certainly, investigations required for holding time during the treatment is found to be inadequate. In this perspective, the present study is being carried out to evaluate the performance during turning of low carbon steel at different cutting parameters such as Spindle Speed, feed and depth of cut using Liquid Nitrogentreated M2 tool steel. Liquid Nitrogen-treatment of M2 Tools was carried out at 12 hours, 24 hours, 36 hours holding time followed by tempering at $150{ }^{\circ} \mathrm{C}$. The tool wear, cutting forces and surface roughness are analyzed during the turning process. The tests were conducted using Taguchi technique to find the optimum values. Finally, using SEM and EDAX analysis, the wear mechanism of the cryo-treated tools was evaluated.

\section{MATERIALS AND PROCEDURE}

\subsection{Material for Work piece}

Low carbon steel with carbon percentage $0.19 \%$ is selected for carrying out the turning experiments as it is the most commonly and widely used type of steel in industrial applications. Low carbon steel, commonly known as mild steel makes itself compatible for variety of applications because of physical and economical aspects. Low carbon steel having measurements of $250 \mathrm{~mm}$ length and $40 \mathrm{~mm}$ diameter was used for turning study. The chemical properties of low carbon steel are shown in Table 1.

Table 1: Chemical analysis results of low carbon steel.

\begin{tabular}{ccc}
\hline Sr No & Content & Percent (\%) \\
\hline 1 & $\mathrm{C}$ & 0.19 \\
2 & $\mathrm{Fe}$ & 98.84 \\
3 & $\mathrm{Mn}$ & 0.85 \\
4 & $\mathrm{P}$ & $<0.030$ \\
5 & $\mathrm{~S}$ & $<0.043$ \\
\hline
\end{tabular}

\subsection{Cutting Tool Material}

In the present study, a Liquid Nitrogen-treated single point cutting tool of AISI M2 tool steel having dimensions $12 \times 12 \times 80 \mathrm{~mm}$ is used. The treatment was carried out for 12 hours, 24 hours, 36 hours holding time. The tool geometry was prepared as per ISO grade: Side rake angle of $4^{\circ}$, Side cutting edge angle of $30^{\circ}$, End relief angle of $8^{\circ}$, Back rake angle of $14^{\circ}$ and Nose radius $=$ $0.4 \mathrm{~mm}$. The chemical composition of the M2 tool steel is as in Table 3.

Table 2: Chemical analysis results showing the proportion of alloys in M2 tool steel

\begin{tabular}{ccc}
\hline Sr No & Content & Percent (\%) \\
\hline 1 & $\mathrm{~W}$ & 6.404 \\
2 & $\mathrm{~V}$ & 1.912 \\
3 & $\mathrm{Mo}$ & 4.549 \\
4 & $\mathrm{Cr}$ & 4.19 \\
5 & $\mathrm{~S}$ & 0.022 \\
6 & $\mathrm{P}$ & 0.028 \\
7 & $\mathrm{Mn}$ & 0.241 \\
8 & $\mathrm{Si}$ & 0.262 \\
9 & $\mathrm{C}$ & 0.864 \\
\hline
\end{tabular}

\subsection{Liquid nitrogen Treatment}

Primarily, the single point cutting tools were subjected heat treatment process at an austenitizing temperature in the vacuum furnace and later quenching of specimens via Oil and air to bring back the tools to room temperature. The heat-treated samples were then subjected to liquid nitrogen for the Liquid Nitrogen-treatment process at $-196{ }^{\circ} \mathrm{C}$ at $1{ }^{\circ} \mathrm{C} / \mathrm{min}$ cooling rate. The treatment was carried out at 12 hours, 24 hours and 36 hours holding time. The complete process was supported by a controlled chamber. Quickly after the Liquid Nitrogentreatment, the tools were subjected to tempering at 200 ${ }^{0} \mathrm{C}$ for 2 hours. The samples were then designated based on the cryogenic soaking hour as LN-12 for 12 hours, LN-24 for 24 hours and LN-36 for 36 hours holding time. Figure. 1 depicts the Liquid Nitrogen-treatment cycle for AISI M2 steel.

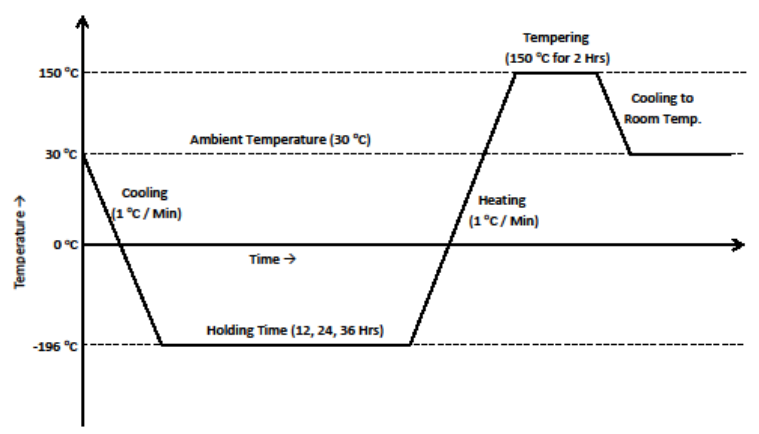

Figure 1. Liquid Nitrogen-Treatment Cycle.

\subsection{Setup Used for Experimentation}

The turning study was carried out on CNC (Computer numerically controlled) HAAS make (GT-10) turning machine. Cutting force, Tool wear and surface roughness were selected as the response study. The cutting forces were evaluated during the turning process using the lathe tool dynamometer based on the microcontroller. For statistical analysis, the resulting force F calculated using Equation (1) is regarded. For each experiment with a set cutting moment of $5.0 \mathrm{~min}$, the fresh cutting tool was used. At each condition, the tests were performed twice to maintain minimum errors. The RTM -500 (Radical) instrument manufacturer's microscope was used to assess the tool flank wear. The surface roughness $(\mathrm{Ra})$ was evaluated on the machined surface at three distinct places using Surftest-10 (Matrix) surface roughness tester at a cutting length of $0.08 \mathrm{~mm}$ at ambient temperature as per ANSI B46.1 standard. The dry turning process flow is as shown in Figure. 2.

$$
F_{M}=\sqrt{f_{c}^{2}+f_{f}^{2}+f_{t}^{2}}
$$

where $\mathrm{FM}=$ Mean force

$\mathrm{Fc}=$ cutting force

$\mathrm{Ff}=$ feed force

$\mathrm{Ft}=$ thrust force [26]

Taguchi's L27 orthogonal array was considered for experimentation. The software MINITAB-16 was used to analyze output reactions such as surface roughness, 
wear of tools and cutting power. The $\mathrm{S} / \mathrm{N}$ ratio was calculated using ' lower the better ' as provided in the equation 2 for all output response [24].

$$
\frac{S}{N}=-10 \log 1 / n\left(\sum y^{2}\right)
$$

\section{RESULTS AND DISCUSSION:}

\subsection{Microhardness}

Microhardness tests were carried out on OmniTech (MVH-II) Microhardness tester as per ASTM E384-17 standards with a load of about 1000 grams and dwell time of $30 \mathrm{Sec}$. The average of three values was considered as final Microhardness value. The effect of microhardness values of AISI M2 tool steel can be found from figure 3 with $\mathrm{LN}$ at different holding time. The hardness tends to increase of about $65 \%$ after $\mathrm{LN}$ when compared with untreated specimens. It is observed that with an increase in holding time from LN-12 to LN-24 hours a slight increase in the hardness value was found. The increase in hardness value was found to be marginal of about $10.47 \%$ for $\mathrm{LN}-24$ hours holding time when compared with $\mathrm{LN}-12$ hours. It is due to the phase transformation where the retained austenite is converted into martensite and distribution of finer carbide structure in the matrix [25]. Further, as the holding time was varied from $\mathrm{LN}-24$ hours to $\mathrm{LN}-36$ hours there was a drop in the hardness of about $4.26 \%$ when compared to LN-24 hours holding time. The drop in the value is due to the dislocation of the carbides in the tempered martensite structure for M2 tool steel [4].

\subsection{Turning Study}

Turning study experiments of cryogenically treated tool steel for different holding time was conducted based on the design of experiments. Based on the number of factors and their levels, L27 $\left(3^{13}\right)$ orthogonal array was selected for experiments $[25,27]$. The analysis of the experimental values was carried out using MINITAB 16 software. The S-N Ratio calculated using Taguchi's 'smaller the better' quality characteristic for all output response as shown in table 3.ANOVA analysis was also carried out table 4,5 and 6 illustrate the process parameters with $\mathrm{F}$ values and p-values for tool wear, surface roughness and cutting forces. The 95\% confidence interval and $\alpha=0.05$ significance level were selected for the analysis. The last column of the tables shows the $\%$ contribution $(\mathrm{P})$ of each variable. The $\%$ contribution was calculated by equation 3 .

$$
P \%=\operatorname{seq} S S / \operatorname{seq} S T
$$

\subsubsection{Effect on tool wear}

The tool wear was measured by measuring the flank wear using 'Tool maker's microscope'. Table 3 shows the tool wear for 27 different parameter combinations suggested by Taguchi's L-27 array. The table shows that minimum tool wear of $0.055 \mathrm{~mm}$ was obtained at LN-24 hours of holding time and maximum tool wear of $0.209 \mathrm{~mm}$ was obtained at LN-12 hours holding time. The optimum process parameters observed for minimum tool wear were, 'Spindle Speed' $700 \mathrm{rpm}$, 'feed' $0.125 \mathrm{~mm}$ and 'depth of cut' $0.15 \mathrm{~mm}$. It was also

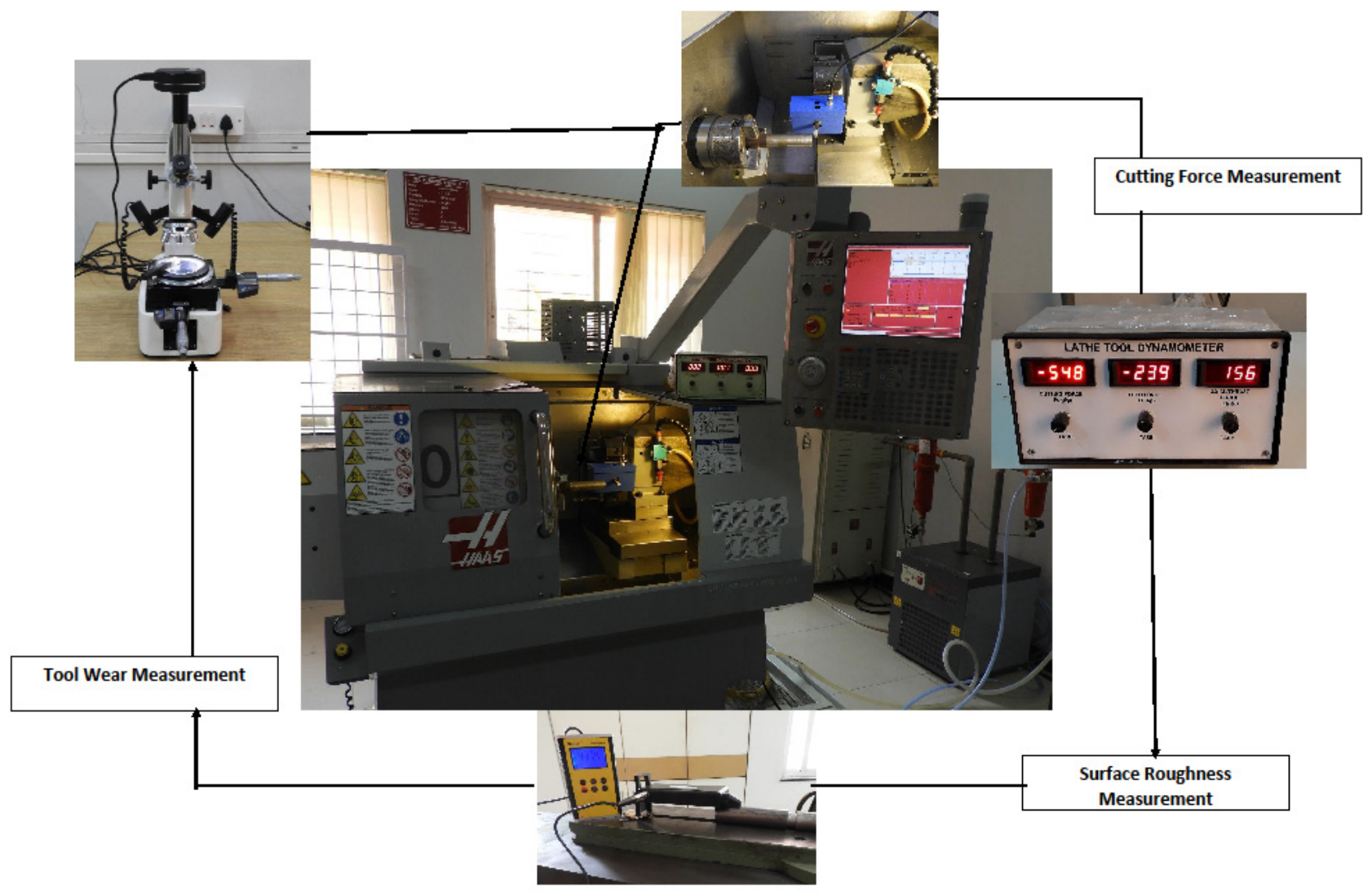

Figure 2: Dry Turing - Output response measurement flow 
Table 3: Experimental results for measuring performance according to the layout of Taguchi (L27)

\begin{tabular}{|c|c|c|c|c|c|c|c|c|c|c|}
\hline Sl.no & $\mathrm{T}$ (Hours) & $\begin{array}{c}\mathrm{Vc} \\
(\mathrm{RPM})\end{array}$ & $\mathrm{F}(\mathrm{mm} / \mathrm{rev})$ & $\mathrm{D}(\mathrm{mm})$ & $\begin{array}{c}\mathrm{VB} \\
\max \\
(\mathrm{mm}) \\
\end{array}$ & S-N Ratio & $\operatorname{Ra}(\mu \mathrm{m})$ & S-N Ratio & CF (Kgf) & S-N Ratio \\
\hline 1 & 12 & 700 & 0.1 & 0.15 & 0.086 & 21.31003 & 2.733333 & -8.73385 & 21.04757 & -28.5552 \\
\hline 2 & 12 & 700 & 0.125 & 0.3 & 0.209 & 13.59707 & 2.9 & -9.54243 & 24.5153 & -28.657 \\
\hline 3 & 12 & 700 & 0.15 & 0.45 & 0.156 & 16.13751 & 3.566667 & -10.9637 & 30.38092 & -29.8318 \\
\hline 4 & 24 & 1100 & 0.1 & 0.15 & 0.082 & 21.72372 & 2.1 & -6.0206 & 19.0263 & -26.7578 \\
\hline 5 & 24 & 1100 & 0.125 & 0.3 & 0.081 & 21.8303 & 2.6666667 & -8.41012 & 21.93171 & -25.563 \\
\hline 6 & 24 & 1100 & 0.15 & 0.45 & 0.135 & 17.39332 & 2.953333 & -9.30766 & 28.08914 & -27.7379 \\
\hline 7 & 36 & 1800 & 0.1 & 0.15 & 0.117 & 18.63628 & 2.266667 & -7.23456 & 22.84732 & -26.6652 \\
\hline 8 & 36 & 1800 & 0.125 & 0.3 & 0.158 & 16.02686 & 2.466667 & -7.72403 & 28.4605 & -26.9636 \\
\hline 9 & 36 & 1800 & 0.15 & 0.45 & 0.18 & 14.89455 & 2.9 & -9.04595 & 30.74085 & -28.0889 \\
\hline 10 & 24 & 1800 & 0.1 & 0.3 & 0.105 & 19.57621 & 2.2 & -6.97907 & 21.77154 & -24.7567 \\
\hline 11 & 24 & 1800 & 0.125 & 0.45 & 0.135 & 17.39332 & 2.533333 & -8.18739 & 26.09598 & -27.2673 \\
\hline 12 & 24 & 1800 & 0.15 & 0.15 & 0.125 & 18.0618 & 2.433333 & -8.07385 & 23.43075 & -26.0746 \\
\hline 13 & 36 & 700 & 0.1 & 0.3 & 0.131 & 17.65457 & 2.366667 & -7.35954 & 29.06888 & -27.4663 \\
\hline 14 & 36 & 700 & 0.125 & 0.45 & 0.133 & 17.52297 & 3 & -9.34723 & 32.4037 & -29.7864 \\
\hline 15 & 36 & 700 & 0.15 & 0.15 & 0.086 & 21.31003 & 3.1 & -9.54243 & 31.20897 & -28.1224 \\
\hline 16 & 12 & 1100 & 0.1 & 0.3 & 0.129 & 17.78821 & 2.933333 & -9.14754 & 21.77154 & -27.4586 \\
\hline 17 & 12 & 1100 & 0.125 & 0.45 & 0.162 & 15.8097 & 3.233333 & -9.92013 & 25.19921 & -29.1275 \\
\hline 18 & 12 & 1100 & 0.15 & 0.15 & 0.154 & 16.24959 & 2.666667 & -8.29947 & 22.09072 & -28.5552 \\
\hline 19 & 36 & 1100 & 0.1 & 0.45 & 0.127 & 17.92393 & 3.033333 & -8.62728 & 27.74887 & -27.0757 \\
\hline 20 & 36 & 1100 & 0.125 & 0.15 & 0.095 & 20.44553 & 2.833333 & -8.83914 & 26.83282 & -25.2244 \\
\hline 21 & 36 & 1100 & 0.15 & 0.3 & 0.13 & 17.72113 & 2.933333 & -9.10705 & 29.06888 & -28.1757 \\
\hline 22 & 12 & 1800 & 0.1 & 0.45 & 0.185 & 14.65657 & 2.5 & -7.72403 & 23.04344 & -28.5552 \\
\hline 23 & 12 & 1800 & 0.125 & 0.15 & 0.12 & 18.41638 & 2.766667 & -8.73385 & 17.72005 & -27.1767 \\
\hline 24 & 12 & 1800 & 0.15 & 0.3 & 0.185 & 14.65657 & 3.133333 & -9.92013 & 22.02272 & -28.1757 \\
\hline 25 & 24 & 700 & 0.1 & 0.45 & 0.086 & 21.31003 & 2.6 & -8.41012 & 29.69848 & -27.5435 \\
\hline 26 & 24 & 700 & 0.125 & 0.15 & 0.055 & 25.19275 & 2.766667 & -8.83914 & 27.38613 & -26.2118 \\
\hline 27 & 24 & 700 & 0.15 & 0.3 & 0.082 & 21.72372 & 2.833333 & -9.04595 & 30.03331 & -28.9042 \\
\hline
\end{tabular}

observed that the range of tool wear for LN-12 hours of holding time was $0.086 \mathrm{~mm}$ to $0.209 \mathrm{~mm}$, the range of tool wear for LN-24 hours was $0.055 \mathrm{~mm}$ to $0.135 \mathrm{~mm}$ and the range of tool wear for LN-36 hours was also $0.086 \mathrm{~mm}$ to $0.18 \mathrm{~mm}$. It was observed that the overall range of tool wear for $\mathrm{LN}-24$ hours holding time shows minimum tool wear compare to LN-12 and LN-36 hours of holding time.

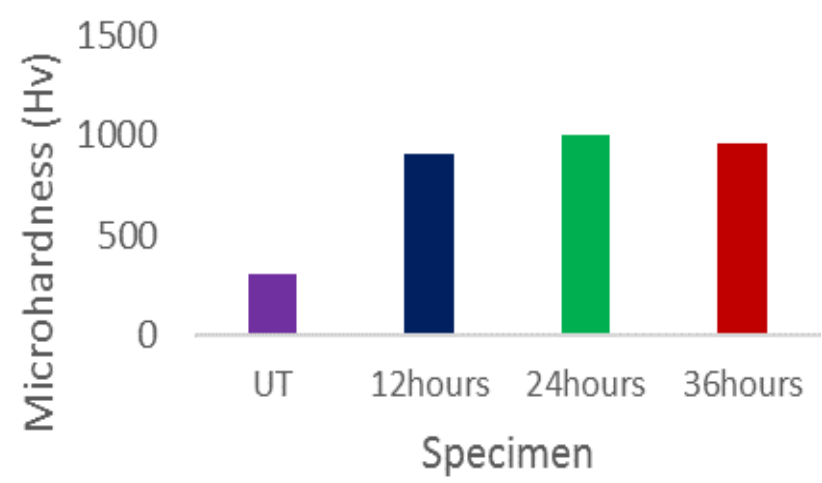

Figure 3. Microhardness results of M2 tool steel

Significant parameter for tool wear for specimen LN treated with different holding time was identified using ANOVA which can be seen in table 4 . Based on the Pvalue, the percentage contribution in wear by each parameter was calculated. The last column shows the value of $\%$ contribution of the variables were holding time contributes the maximum (35.6\%), followed by the depth of cut $(23.8 \%)$, Spindle Speed (15.4\%) and feed $(4.5 \%)$. The interaction of Spindle Speed and depth of cut $(8.47 \%)$ is also influencing the tool wear.
Table 4: Tool Wear - ANOVA

\begin{tabular}{|c|c|c|c|c|c|c|c|}
\hline Source & DF & Seq SS & Adj SS & Adj MS & $\mathrm{F}$ & $\mathrm{P}$ & $\mathrm{P}(\%)$ \\
\hline$T$ & 2 & 71.699 & 71.699 & 35.8497 & 42.27 & 0.000 & 35.6 \\
\hline $\mathrm{Vc}$ & 2 & 31.125 & 31.125 & 15.5624 & 18.35 & 0.003 & 15.4 \\
\hline $\mathrm{F}$ & 2 & 8.845 & 8.845 & 4.4224 & 5.21 & 0.049 & 4.5 \\
\hline D & 2 & 47.753 & 47.753 & 23.8764 & 28.15 & 0.001 & 23.8 \\
\hline $\mathrm{Vc} * \mathrm{~F}$ & 4 & 8.276 & 8.276 & 2.0689 & 2.44 & 0.158 & 4.2 \\
\hline $\mathrm{Vc} * \mathrm{D}$ & 4 & 17.058 & 17.058 & 4.2645 & 5.03 & 0.040 & 8.4 \\
\hline$F^{*} \mathrm{D}$ & 4 & 11.058 & 11.058 & 2.7645 & 3.26 & 0.096 & 5.5 \\
\hline Error & 6 & 5.088 & 5.088 & 0.8480 & & & \\
\hline Total & 26 & 200.902 & & & & & \\
\hline \multicolumn{8}{|c|}{$\mathrm{S}=0.9209$} \\
\hline
\end{tabular}

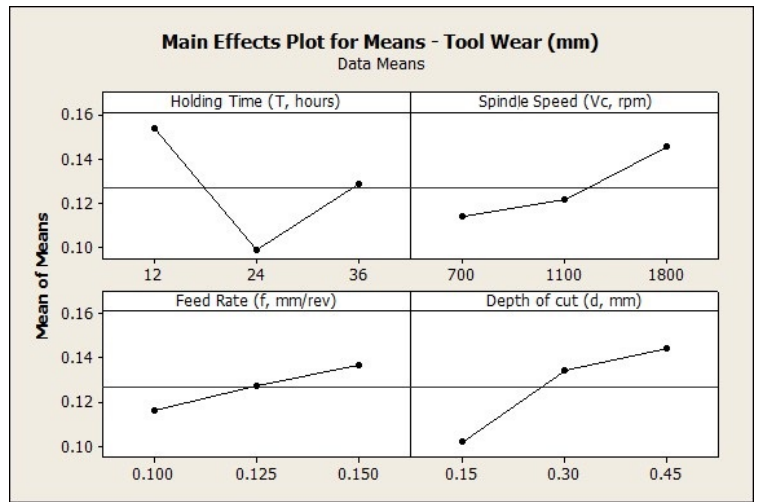

Figure 4: Main effect plot - Tool wear

Figure 4 shows the main effect plot for means of tool wear. Main effect plot shows that tool wear is decreasing as the holding time is increasing from LN-12 to LN-24 hours and later by increasing the holding time the tool wear. So considering the quality characteristics, LN-24 hours observed as optimum holding time. It can be commented that LN-24 hours of holding time refine 
the grain structure of tool steel to the extent that it shows maximum resistance to wear. It was also observed that as the speed of the cutting tool increases there is an increase in the tool wear. For variation in the Spindle Speed from 700 to $1800 \mathrm{rpm}$ there is an increase in tool wear from 0.11 to $0.15 \mathrm{~mm}$. Due to high Spindle Speed, there is an increase in the forces generated during machining resulting in increase of the tool wear. For variation in the feed rate of the cutting tool from 0.1 $\mathrm{mm} / \mathrm{rev}$ to $1.15 \mathrm{~mm} / \mathrm{rev}$ as the feed increases the point of contact of the cutting tool with the workpiece in a given point of time, which exposes the tool to continuous acting of forces, resulting in deteriorating the tool life. Similar is the case with an increase in depth of cut which increases the surface contact of cutting edge with the workpiece. This results in increasing the temperature between the tool and workpiece due to high friction. Increase in the temperature makes the tool material softer making it more prone to wear and tear.

\subsubsection{Effect on surface roughness}

Table 3 shows the average surface roughness value as per trial conditions. From the table, it can be seen that the surface roughness values are ranging from $2.1 \mu \mathrm{m}$ to $3.56 \mu \mathrm{m}$. During analyzing the Ra values with respect to the soaking temperature, it was observed that for holding time LN-12 hours surface roughness values were varying from $2.5 \mu \mathrm{m}$ to $3.566 \mu \mathrm{m}$, for holding time LN24 hours surface roughness values were varying from $2.1 \mu \mathrm{m}$ to $2.953 \mu \mathrm{m}$, and for LN-36 hours surface roughness values were varying from $2.266 \mu \mathrm{m}$ to 3.1 $\mu \mathrm{m}$. It was observed that the overall range of surface roughness for $\mathrm{LN}-24$ hours holding time shows minimum surface roughness value compared to $\mathrm{LN}-12$ hours and LN-36 hours of holding time.

Table 5: Surface roughness - ANOVA

\begin{tabular}{|c|c|c|c|c|c|c|c|}
\hline Source & DF & Seq SS & Adj SS & Adj MS & $\mathrm{F}$ & $\mathrm{P}$ & $\mathrm{P}(\%)$ \\
\hline$T$ & 2 & 6.2716 & 6.2716 & 3.1358 & 21.48 & 0.002 & 21.2 \\
\hline $\mathrm{Vc}$ & 2 & 4.5349 & 4.5349 & 2.2675 & 15.54 & 0.004 & 15.3 \\
\hline $\mathrm{F}$ & 2 & 8.6483 & 8.6483 & 4.3241 & 29.63 & 0.001 & 29.2 \\
\hline D & 2 & 4.0496 & 4.0496 & 2.0248 & 13.87 & 0.006 & 13.7 \\
\hline $\mathrm{Vc} * \mathrm{~F}$ & 4 & 1.4158 & 1.4158 & 0.3539 & 2.42 & 0.159 & 4.8 \\
\hline$V c^{*} D$ & 4 & 2.6325 & 2.6325 & 0.6581 & 4.51 & 0.051 & 8.9 \\
\hline$F^{*} \mathrm{D}$ & 4 & 1.2031 & 1.2031 & 0.3008 & 2.06 & 0.205 & 4.06 \\
\hline Error & 6 & 0.8757 & 0.8757 & 0.1460 & & & \\
\hline \multirow[t]{2}{*}{ Total } & 26 & 29.6315 & & & & & \\
\hline & $\mathrm{S}=$ & $3820 \quad \mathrm{R}$ & & $\mathrm{R}-$ & dj) & $9.2 \%$ & \\
\hline
\end{tabular}

Significant parameter for tool wear for specimens cryo-treated with different holding time was identified using Analysis of variance (ANOVA) which can be seen in table 5. Based on the P-value, the percentage contribution in wear by each parameter was calculated. The last column shows the percentage contribution of all the variables wherein maximum contribution was noticed from feed $(29.2 \%)$ followed by holding time $(21.2 \%)$, depth of cut (13.7\%), Spindle Speed (15.3\%).

It can be seen from the figure 5 that within the scope of this investigation that the surface roughness is decreasing as the holding time is increasing from $\mathrm{LN}-12$ to $\mathrm{LN}-24$ hours and later by increasing the holding time to LN-36 hours the surface roughness is again increasing. So LN-24 hours can be considered as optimum holding time. It is also observed that as the speed of the cutting tool increases there is a decrease in surface roughness values. For variation in the Spindle Speed from 700 to $1800 \mathrm{rpm}$ there is a decrease in surface roughness from 2.85 to $2.4 \mu \mathrm{m}$. The improvement in surface roughness is because of high material removal from the same length of the workpiece, which is a result of the high Spindle Speed of the cutting tool. Lower speed of the cutting tool deteriorates the surface roughness. So higher Spindle Speed is desired for optimum performance for surface roughness, as the feed rate of the cutting tool increases, there is an increase in the average value of surface roughness. For variation in the feed rate of cutting tool from $0.1 \mathrm{~mm} / \mathrm{rev}$ to 1.15 $\mathrm{mm} / \mathrm{rev}$ as the feed increases the material removal rate also increases, which deteriorates the surface roughness. So lower feed rate is desired for the achievement of good surface roughness. Similar is the case with an increase in depth of cut. The increase in depth of cut increases the temperature of the tool and workpiece due to high friction between the tool and workpiece, which in turn increases the surface roughness. So minimum depth of cut is preferred during machining.

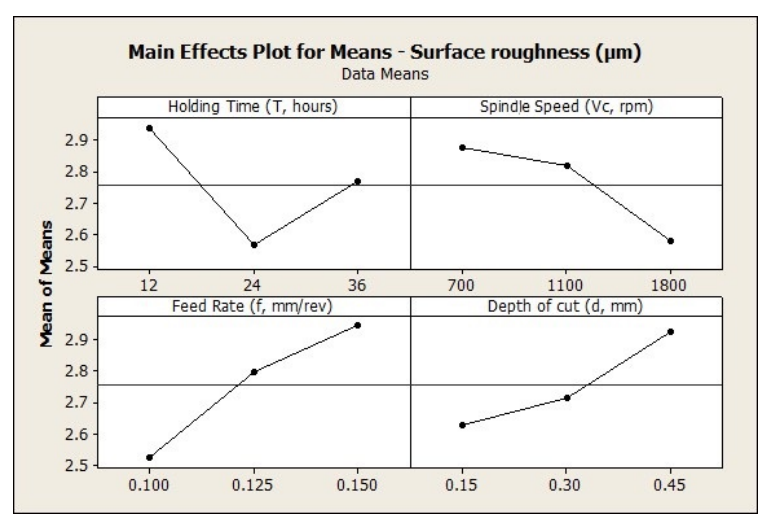

Figure 5: Main effect plot - Surface roughness

\subsubsection{Effect on cutting forces}

Table 3 shows the average cutting force value as per trial conditions The optimum process parameters observed for minimum cutting forces were, Spindle Speed $1800 \mathrm{rpm}$, feed $0.125 \mathrm{~mm}$ and depth of cut $0.15 \mathrm{~mm}$. It was also observed that the range of cutting forces for LN-12 hours of holding time was $17.72 \mathrm{Kgf}$ to 30.38 Kgf, the range of cutting for LN-24 hours holding time was $19.02 \mathrm{Kgf}$ to $30.03 \mathrm{Kgf}$ and the range of cutting force for LN-36 hours holding time was. It was observed that the overall range of tool wear for LN-24 hours holding time is minimal compared to $\mathrm{LN}-12$ and LN-36 hours of holding time.

Table 6 depicts the ANOVA results of cutting forces. It was observed that the P-value for holding time (0.002) is minimum followed by Spindle Speed (0.005) and followed by the depth of cut $(0.005)$. This gives a clear understanding that holding time is the most significant factor with percentage contribution (29\%) followed by cutting forces the second most significant parameter with percentage contribution of (18.8\%) and third most significant parameter depth of cut with percentage contribution of $(12.4 \%)$. In the case of interactions, none of the interaction has $\mathrm{P}$ value less than 0.005 
which shows that there is no interaction affecting the cutting force generated during experimentation.

Table 6: Cutting forces - ANOVA

\begin{tabular}{|c|c|c|c|c|c|c|c|}
\hline Source & DF & Seq SS & Adj SS & Adj MS & $\mathrm{F}$ & $\mathrm{P}$ & $\mathrm{P}(\%)$ \\
\hline$T$ & 2 & 13.0225 & 13.022 & 6.5113 & 22.54 & 0.002 & 29.9 \\
\hline $\mathrm{Vc}$ & 2 & 8.1909 & 8.1909 & 4.0955 & 14.18 & 0.005 & 18.8 \\
\hline $\mathrm{F}$ & 2 & 5.1269 & 5.1269 & 2.5635 & 8.87 & 0.016 & 11.8 \\
\hline $\mathrm{D}$ & 4 & 8.2597 & 8.2597 & 4.1299 & 14.30 & 0.005 & 18.9 \\
\hline $\mathrm{Vc} * \mathrm{~F}$ & 4 & 1.3293 & 1.3293 & 0.3323 & 1.15 & 0.417 & 3.1 \\
\hline $\mathrm{Vc} * \mathrm{D}$ & 4 & 0.5191 & 0.5191 & 0.1298 & 0.45 & 0.771 & 1.2 \\
\hline $\mathrm{F}^{*} \mathrm{D}$ & 4 & 5.3673 & 5.3673 & 1.3418 & 4.64 & 0.048 & 12.4 \\
\hline Error & 6 & 1.7333 & 1.7333 & 0.2889 & & & \\
\hline Total & 26 & 43.5491 & & & & & \\
\hline \multicolumn{8}{|c|}{$\mathrm{S}=0.5375$} \\
\hline
\end{tabular}

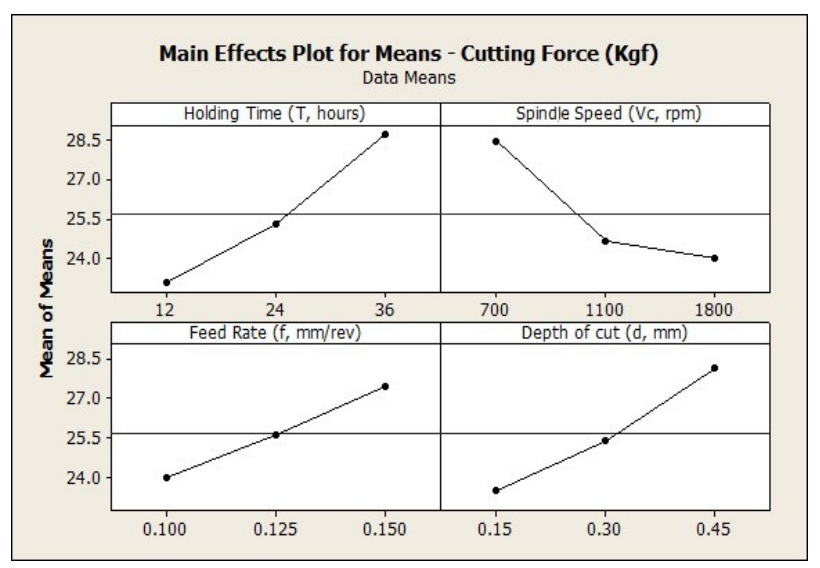

Figure 6: Main effect plot - Cutting Force

It can be seen from Figure 6 that within the scope of this investigation the cutting forces recorded during machining are decreasing as the holding time is increasing from LN-12 to LN-24 hours and later by increasing the holding time of the tool wear. So LN-24 hours can be considered as optimum holding time. It is also observed that as Spindle Speed of the cutting tool increases, there is a decrease in the machining force. For variation in cutting tool speed from $700 \mathrm{rpm}$ to $1800 \mathrm{rpm}$, the average machining force remains the same. With the increase in Spindle Speed, the shear angle increases, resulting in chip thickness size reduction and hence the machining force decreases. So higher Spindle Speed is desired for optimum performance of forces, as feed rate of the cutting tool increases, the contact area of the work part and tool increases, which in turn increases the machining forces. The increase in machining force due to increase in feed rate is evident from the graph. Similar behavior is observed in the case of depth of cut, an increase in depth of cut increases the machining forces. So higher Spindle Speed with a combination of low feed and depth of cut is essential in reducing the forces, which in turn improves the tool life.

\section{SEM IMAGES OF TOOL TIP}

Figure 7 depicts the SEM images of M2 Liquid Nitrogen treated tool samples. Figure $7(a, b)$ shows the SEM images of the tool after cryogenic treatment with LN-12 hours of holding time for machining at the speed of $1800 \mathrm{rpm}, 0.1 \mathrm{~mm}$ feed and $0.45 \mathrm{~mm}$ depth of cut. The images were taken at $250 \mathrm{X}$ zoom and 500X zoom. From the images, it was observed that chipping has taken place at tool edge. Figure 7 (c, d) shows the SEM image of the tool after LN-36 hours of holding time machined with a speed of $1800 \mathrm{rpm} 0.15 \mathrm{~mm}$ feed and $0.45 \mathrm{~mm}$ depth of cut. The images were taken at $250 \mathrm{X}$ zoom and $500 \mathrm{X}$ zoom. It was observed that the tool surface was worn out due to abrasion and delamination on the edges were observed. The surface wear mainly occurred because of high cutting force generated due to a high depth of cut. Very little material was found deposited on the tool surface. Figure $7(\mathrm{e}, \mathrm{f})$ shows the SEM images of the tool after LN-24 hours of holding time of cryo-genic treatment machined at speed of $1800 \mathrm{rpm}, 0.1 \mathrm{~mm}$ feed and $0.3 \mathrm{~mm}$ depth of cut. It was observed that tooltip was damaged after machining. From the images of the tooltip abrasion, diffusion and chipping were found on the tooltip resulting in flank and crater were.
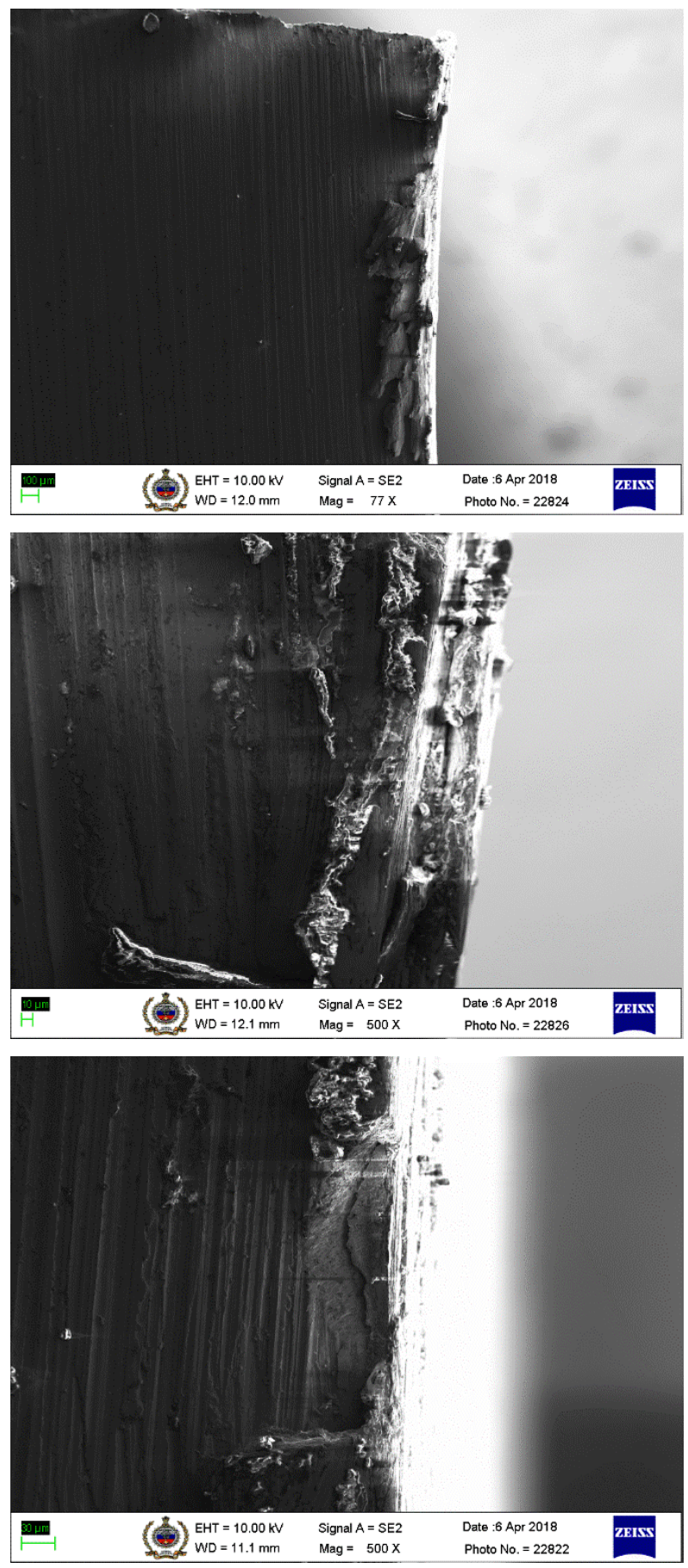

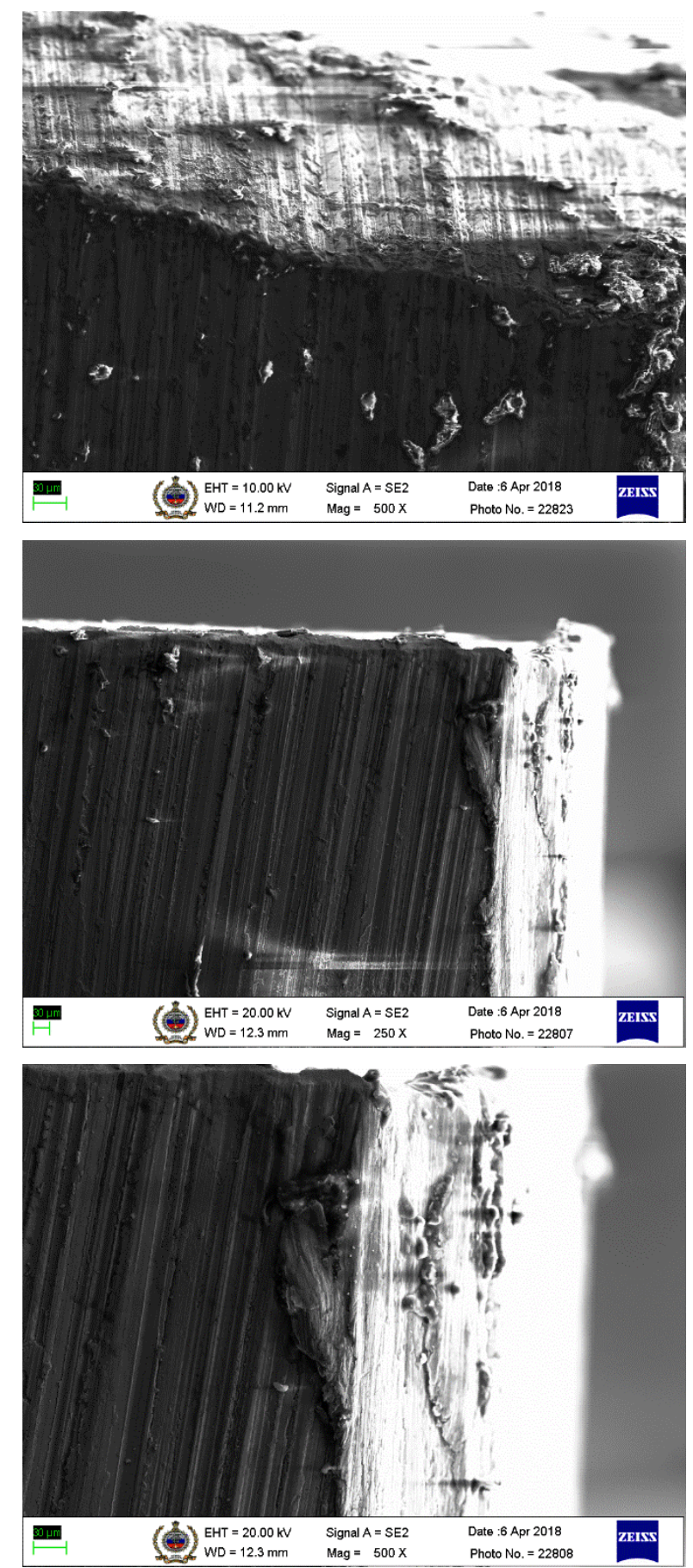

Figure 7: SEM Micrograph images of $(a, b)$ worn surface of LN-12 holding time (c,d) worn surface of LN-36 holding time $(e, f)$ worn surface of $\mathrm{LN}-24$ holding time

\section{REGRESSION ANALYSIS}

Linear regression method was applied to draw out the mathematical relation between output and input parameters. Referring to the results obtained from ANOVA the equations were drawn out for each tool steel material separately. To identify the most significant parameter, the value of ' $\alpha$ ' is compared with the value of ' $\mathrm{P}$ ' and the values of $\mathrm{P}$ which were above 0.05 were neglected during the regression equation as the analysis was done for $95 \%$ confidence interval.

Equation 4-6 shows the correlation between the output variables with respect to input variables.
$V_{b \max }=0.0232-0.00106 X T+0.000030 X C S+$

$+0.411 X F+0.141 X D-0.000001 X C S X D$

$R a=1.81-0.00710 X T-0.000189 X C S+8.41 X F+$ $1.34 X D-0.000296 X C S X D$

$C F=19.9-0.109 X T-0.00297 X C S+54.4 X F+12.0 X D$

\section{EXPERIMENTS FOR CONFIRMATION OF RESULT}

Confirmatory experiments were performed to validate the model equations $4-6$ The Experiments were performed by selecting three new sets of random variables which do not belong to the Design of experiments as a part of validation. The parameters used for confirmatory experiments are shown in Table 8. The confirmatory experiment was denoted as $\mathrm{C} 1, \mathrm{C} 2$ and $\mathrm{C} 3$ respectively.

Table 8: Selected Cutting parameters for conformation test

\begin{tabular}{ccccc}
\hline Sl.no & $\begin{array}{c}\text { T } \\
\text { (Hours) }\end{array}$ & $\begin{array}{c}\text { Vc } \\
\text { (RPM) }\end{array}$ & $\begin{array}{c}\text { F } \\
\text { (mm/rev) }\end{array}$ & $\begin{array}{c}\text { D } \\
\text { (mm) }\end{array}$ \\
\hline C1 & 12 & 800 & 0.12 & 0.2 \\
C2 & 24 & 1200 & 0.16 & 0.4 \\
C3 & 36 & 1600 & 0.18 & 0.5 \\
\hline
\end{tabular}

Table 9: Result of Confirmation test

\begin{tabular}{|c|c|c|c|c|}
\hline Sl.no & Test & Experiment & Model & $\begin{array}{c}\text { Error } \\
(\%)\end{array}$ \\
\hline 1 & \multicolumn{4}{|c|}{ Tool Wear VB max } \\
\hline & $\mathrm{C} 1$ & 0.1173 & 0.1118 & $4.95 \%$ \\
\hline & $\mathrm{C} 2$ & 0.1619 & 0.1554 & $4.23 \%$ \\
\hline & $\mathrm{C} 3$ & 0.1866 & 0.1767 & $5.62 \%$ \\
\hline \multirow[t]{4}{*}{2} & Sur & ce roughness & $\operatorname{Ra}(\mu \mathrm{m})$ & \\
\hline & $\mathrm{C} 1$ & 2.9629 & 2.8034 & $5.69 \%$ \\
\hline & $\mathrm{C} 2$ & 3.3486 & 3.1523 & $6.23 \%$ \\
\hline & $\mathrm{C} 3$ & 3.3583 & 3.1990 & $4.98 \%$ \\
\hline 3 & \multicolumn{4}{|c|}{ Cutting Forces (Kg) } \\
\hline & $\mathrm{C} 1$ & 25.4306 & 25.1440 & $1.14 \%$ \\
\hline & $\mathrm{C} 2$ & 28.0026 & 27.2240 & $2.86 \%$ \\
\hline & $\mathrm{C} 3$ & 27.7076 & 27.0160 & $2.56 \%$ \\
\hline
\end{tabular}

Table 9 displays the outcomes gained by comparing the values acquired from the mathematical model created using the random variable (Eqs. (4) - (6)); with the values obtained from the experiments carried out using the variables from table 5.21. The Error percentage obtained for tool wear VB max (max. value $5.62 \%$ and $\min .4 .23 \%)$, Surface roughness Ra $(\mu \mathrm{m})$ ( $\max$. value $6.23 \%$ and $\min .4 .98 \%$ ) and Cutting Forces (Kgf) (max. value $2.86 \%$ and $\min .1 .14 \%$ ) for M2 tool steel when compared with predicted values obtained from the model are not exceeding $7 \%$ which is in the accepted limit. Therefore the mathematical models obtained for tool wear, cutting forces and surface roughness are within the degree of approximation.

\section{CONCLUSION:}

The study is aimed at Liquid nitrogen treatment of M2 tool steels and evaluating the effect of different holding durations on the machining performance during turning operations. The study was carried out using M2 singlepoint cutting tools which were Liquid nitrogen treated for 12 hours, 24 hours, and 36 hours durations at $196^{\circ} \mathrm{C}$ temperature. The material selected for turning 
experiments was low carbon steel with $0.19 \%$ carbon content. Tests were conducted as per the order generated by Taguchi's L27 orthogonal array. Three variables, namely Spindle Speed, Feed rate, and Depth of cut, were used with three levels to experimentally analyze the quality of machining and its effect on tool wear. Following conclusions can be made from the results of the study:

The observation of microscopic images after experimentation indicates that the 24 hour Liquid nitrogen treated tool exhibited a minimum tool (flank) wear of 0.055 $\mathrm{mm}$ with machining variables set to $700 \mathrm{rpm}$ speed, 0.125 $\mathrm{mm} / \mathrm{rev}$ feed rate and $0.15 \mathrm{~mm}$ depth of cut. The maximum tool wear of $0.209 \mathrm{~mm}$ was observed for the specimen with 12 hours LNT with machining parameters set to $700 \mathrm{rpm}$ speed, $0.125 \mathrm{~mm} / \mathrm{rev}$ feed rate and $0.3 \mathrm{~mm}$ depth of cut. From these observations, it can be concluded that the maximum tool (flank) wear was observed for 12 hours LNT and minimum for 24 hours LNT.

The surface roughness of the machined surface was measured considering the Ra parameter, and it can be observed that the value ranges between $2.5 \mu \mathrm{m}$ and $3.566 \mu \mathrm{m}$ for all the experiments. And the machined surface is found to be smoother when the machining is carried out with 24 hour Liquid nitrogen treated tool. The ANOVA of the results indicates that the surface roughness is influenced by feed $(29.2 \%)$ followed by holding time (21.2\%), Depth of cut (13.7\%) and Spindle Speed (15.3\%).

Cutting forces are found to be reducing with 24 hour LNT tools compared to 12 hours and 36 hours LNT tools and for 24 hour LNT tools, the cutting forces were found to range between $22.84 \mathrm{Kgf}$ and $32.40 \mathrm{Kgf}$. ANOVA results indicate that the holding time is the most significant factor influencing the cutting forces with percentage contribution $29 \%$ followed by speed and Depth of cut (18\%) and finally feed rate with a percentage contribution of $(12.4 \%)$.

The SEM analysis of worn surfaces of the tools indicates the chipping phenomenon near the cutting edge, suggesting an impact between the tool and workpiece. The presence of surface wear indicates abrasion and peel off of the tool surface due to higher values of feed rate and Depth of cut during machining. Material deposition from the workpiece to tool surface is found to be minimal for the LNT tools. From the images of the tooltip abrasion, diffusion and chipping were located on the tooltip resulting in flank and crater were.

Linear regression analysis was carried out to build a regression model to predict the tool wear, surface roughness, and coefficient of friction during the machining operations. From the confirmation tests, it is found that the model fits within limits and with a maximum error of around $\pm 6 \%$.

\section{REFERENCES}

[1] Senthilkumar, D. (2019). Tensile and residual stress behaviour of Liquid nitrogenally treated EN31 steel. Advances in Materials and Processing Technologies, 1-12.

[2] Gill, S. S., Singh, J., Singh, R., \& Singh, H. (2012). Effect of cryogenic treatment on AISI M2 high speed steel: metallurgical and mechanical characte- rization. Journal of Materials Engineering and Performance, 21(7), 1320-1326.

[3] Kumar, S., Khedkar, N. K., Jagtap, B., \& Singh, T. P. (2017, August). The effects of cryogenic treatment on cutting tools. In IOP Conference Series: Materials Science and Engineering(Vol. 225, No. 1, p. 012104). IOP Publishing.

[4] Kumar, S., Nagaraj, M., Bongale, A., Khedkar, N. K. (2019). Effect of Liquid nitrogen treatment on the mechanical properties of AISI D3 tool steel. International Journal of Materials Engineering Innovation, 10(2), 98-113.

[5] Surberg, C. H. et al.: (2008). The effect of some heat treatment parameters on the dimensional stability of AISI D2. Cryogenics, 48(1-2), 42-47.

[6] Li, S., Min, N., Li, J., \& Wu, X. (2013). Internal friction measurements of phase transformations during the process of Liquid nitrogen treatment of a tool steel. Cryogenics, 57, 1-5.

[7] Kumar, S., Nagaraj, M., Khedkar, N. K., Bongale, A. (2018). Influence of Liquid nitrogen treatment on dry sliding wear behaviour of AISI D3 die steel. Materials Research Express, 5(11), 116525.

[8] Das, D., Dutta, A. K., Toppo, V., \& Ray, K. K. (2007). Effect of Liquid nitrogen treatment on the carbide precipitation and tribological behavior of D2 steel. Materials and Manufacturing Processes, 22(4), 474-480.

[9] Amini, K., Akhbarizadeh, A., \& Javadpour, S. (2014). Investigating the effect of quench environment and Liquid nitrogen treatment on the wear behavior of AZ91. Materials \& Design (19802015), 54, 154-160.

[10] Akincioğlu, S., Gökkaya, H., \& Uygur, İ. (2015). A review of cryogenic treatment on cutting tools. The International Journal of Advanced Manufacturing Technology, 78(9-12), 1609-1627.

[11] Rodríguez, A. et al. (2012): Surface improvement of shafts by the deep ball-burnishing technique. Surface and Coatings Technology, 206(11-12), 2817-2824.

[12] Fernández-Abia, A. I., Barreiro, J., de Lacalle, L. N. L., \& Martínez-Pellitero, S. (2012). Behavior of austenitic stainless steels at high speed turning using specific force coefficients. The International Journal of Advanced Manufacturing Technology, 62(5-8), 505-515.

[13] Carlson, E.: Cold treating and cryogenic treatment of steel. ASM Int. ASM Handb. 4, 203-206 (1991)

[14] Akıncioğlu, S., Gökkaya, H., \& Uygur, İ. (2016). The effects of cryogenic-treated carbide tools on tool wear and surface roughness of turning of Hastelloy C22 based on Taguchi method. The International Journal of Advanced Manufacturing Technology, 82(1-4), 303-314.

[15] Ramji, B. R., Murthy, H. N., \& Krishna, M. (2010). Performance study of cryo treated HSS drills in drilling cast iron. International Journal of Engineering Science and Technology, 2(7), 2530-2536. 
[16] Sreerama Reddy T. et al. (2009): Machinability of C45 steel with Liquid nitrogen treated tungsten carbide cutting tool inserts. International Journal of Refractory Metals and Hard Materials, 27(1), 181185.

[17] Firouzdor, V., Nejati, E., Khomamizadeh, F. (2008). Effect of Liquid nitrogen treatment on wear resistance and tool life of M2 HSS drill. Journal of materials processing technology, 206(1-3), 467-472.

[18] Çiçek, A., Uygur, I., Kıvak, T., \& Özbek, N. A. (2012). Machinability of AISI 316 austenitic stainless steel with cryogenically treated M35 high-speed steel twist drills. Journal of Manufacturing Science and Engineering, 134(6), 061003.

[19] Podgornik, B., Paulin, I., Zajec, B., Jacobson, S., \& Leskovšek, V. (2016). Liquid nitrogen treatment of tool steels. Journal of Materials Processing Technology, 229, 398-406.

[20] Asiltürk, I., \& Akkuş, H. (2011). Determining the effect of cutting parameters on surface roughness in hard turning using the Taguchi method. Measurement, 44(9), 1697-1704

[21] Sahin, Y. (2009). Comparison of tool life between ceramic and cubic boron nitride $(\mathrm{CBN})$ cutting tools when machining hardened steels. Journal of materials processing technology, 209(7), 3478-3489

[22] Jadhav, P., Kumar, S., Bongale, A., \& Khedkar, N. (2019). Influence of Liquid nitrogen cooling on tool wear and surface roughness of coated tungsten carbide inserts using statistical techniques. Materials Research Express, 6(7), 076517.

[23] Kumar, S., Nagraj, M., Bongale, A., \& Khedkar, N. (2018). Liquid nitrogen Treatment of AISI M2 Tool Steel and Optimisation of Its Wear Characteristics Using Taguchi's Approach. Arabian Journal for Science and Engineering, 43(9), 4917-4929.

[24] Karimi, Z. N., Heidary, H., Yousefi, J., Sadeghi, S., \& Minak, G. (2018). Experimental investigation on delamination in nanocomposite drilling. FME Transactions, 46(1), 62-69.
[25] Madić, M. J., Radovanović, M. R. (2011). Optimal selection of ANN training and architectural parameters using Taguchi method: A case study. FME Transactions, 39(2), 79-86.

[26] Basavarajappa, S., Suresh, R., Gaitonde, V. N., \& Samuel, G. L. (2014). Analysis of cutting forces and surface roughness in hard turning of AISI 4340 using multilayer coated carbide tool. International Journal of Machining and Machinability of Materials, 16(2), 169-185.

[27] Sachit, T. S., Mohan, N. (2019). Wear Behavior of Aluminum LM4 Reinforced with $\mathrm{WC}$ and $\mathrm{Ta} / \mathrm{NbC}$ Hybrid Nano-Composites Fabricated Through Powder Metallurgy Technique. FME Transactions, 47(3), 535.

\section{ЕВАЛУАЦИЈА ПЕРФОРМАНСИ ОБРАДЕ М2 РЕЗНОГ АЛАТА ТРЕТИРАНОГ ТЕЧНИМ АЗОТОМ КОД ОБРАДЕ НА СТРУГУ}

\section{С. Кумар, А. Бонгале, Н. Кедкар}

Рад се бави М2 алатним челиком третираним течним азотом у трајању од 12, 24 и 36 часова на температури од $-196^{\circ}$ Ц код кога је потом примењено отпуштање на температури од $150^{\circ}$ Ц. Третирани узорци су коришћени за обраду ниско-угљеничног челика на ЦНЦ стругу при различитим брзинама вретена (700, 110 и $1800 \mathrm{rpm})$, брзини помоћног кретања $(0,1 ; 0,125$ и $0,15 \mathrm{rev} / \mathrm{min})$ и дубини резања $(0,15 ; 0,3$ и $0,45 \mathrm{~mm})$. Тагучијев план експеримената и ANOVA су коришћени за статистичку анализу параметара резања и сила резања код хабања алата и храпавости површине после изведеног експеримента. SEM анализом је испитан тип хабања код резног алата. Регресионом анализом је добијен модел за предикцију вредности храпавости површине, хабања алата и коефицијента трења са максималном грешком $\pm 6 \%$ на основу реалних експерименталних вредности. 